\title{
Soft Tissue Sarcoma of the Head and Neck Clinical TNM Finding v8
}

National Cancer Institute

\section{Source}

National Cancer Institute. Soft Tissue Sarcoma of the Head and Neck Clinical TNM

Finding v8. NCI Thesaurus. Code C136656.

A clinical finding about one or more characteristics of soft tissue sarcoma of the head and neck, following the rules of the TNM AJCC v8 classification system. 